\title{
MEDIATION OF PROFITABILITY ON LIQUIDITY, ACTIVITY, AND LEVERAGE TOWARDS SHARIA SHARES RETURN
}

\author{
Mulyanto Nugroho ${ }^{1 *}$ \\ Universitas 17 Agustus 1945 Surabaya \\ 45, Semolowaru St., Surabaya \\ Indonesia 60118 \\ nugroho@untag-sby.ac.id
}

\author{
Ulfi Pristiana ${ }^{2}$ \\ Universitas 17 Agustus 1945 Surabaya \\ 45, Semolowaru St., Surabaya \\ Indonesia 60118 \\ ulfi@untag-sby.ac.id
}

\begin{abstract}
This research aims to gather empirical evidence on the position of profitability as a mediation variable on liquidity, activity, and leverage on stock returns in manufacturing companies listed on the Indonesian Sharia Stock Index (ISSI) between 2017 and 2019. A sample of 11 was collected using the purposive sampling method. A manufacturing firm registered as a consumer goods industry. According to the findings of this report, liquidity, activity, and leverage all significantly impacted profitability but had no impact on stock returns. Profitability has a significant impact on stock returns, and it is a variable that mediates the full impact of liquidity, activity, and leverage on stock returns.
\end{abstract}

Keywords: Liquidity; Activity; Leverage; Profitability; Stock Returns

\section{ABSTRAK}

Penelitian ini bertujuan untuk mendapatkan bukti empiris tentang peran profitabilitas sebagai variabel mediasi, terhadap likuiditas, aktivitas dan leverage pada return saham pada perusahaan manufaktur yang berada dalam Indeks Saham Syariah Indonesia (ISSI) selama tahun 2017 - 2019. Dengan menggunakan metode pruposive sampling diperoleh sampel 11 perusahaan manufaktur yang terdaftar sebagai industri barang konsumsi. Penelitian ini menemukan bahwa likuiditas, aktivitas dan leverage secara partial berpengaruh signifikan terhadap profitabilitas, tetapi berpengaruh tidak signifikan terhadap pengembalian saham. Profitabilitas berpengaruh signifikan terhadap pengembalian saham dan merupakan variabel yang memediasi penuh pengaruh sebagai likuiditas, aktivitas dan leverage terhadap pengembalian saham.

$\begin{array}{lll}\text { Kata Kunci : } & \text { Likuiditas; Aktivitas; Leverage; Profitabilitas; } \\ & \text { Pengembalian Saham } & \\ \text { JEL Classification: } & \text { M41 }\end{array}$

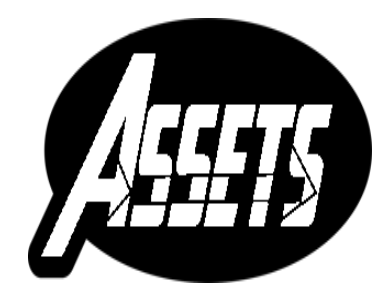

ASSETS

Jurnal Akuntansi dan Pendidikan Vol. 10 No. 1 Page 73-86

Madiun, April 2021 p-ISSN: 2302-6251 e-ISSN: 2477-4995

Article History Submitted: February 26, 2021 Accepted: April 30, 2021 


\section{INTRODUCTION}

Every business, particularly those that go public, will always expect optimal company growth. This is since any corporation that goes public seeks to enhance the well-being of its shareholders. This urge would arise in companies that use either conventional or Sharia methods. When choosing an investment, an investor must make one of the essential decisions whether to use Sharia or traditional methods. According to Beik \& Fatmawati (2014), the rise of Islamic products in the capital market is driven by a desire to fulfill the needs of people who want to invest based on Sharia values. Furthermore, assessment of Islamic stocks is typically chosen because it provides investors with assurance that the gains from controlled funds do not include usury. On July 3, 1999, PT Danareksa Investment Management launched Danareksa Syariah. In the same year, the Indonesia Stock Exchange (IDX) launched the Jakarta Islamic Index in partnership with PT Danareksa Investment Management (JII). This demonstrates that Islamic stocks are generally accepted in a variety of circles. Like that of traditional stocks, share ownership aims to enhance shareholders' welfare.

According to Brigham \& Houston (2015), signaling theory notes that stock returns are a signal for investors representing shareholder prosperity, either in the form of dividends or capital gains. This is similar to Sharia shares, except the principles used in Sharia shares are benefit-sharing, selling, purchasing, and lending because the profit orientation is for the hereafter, so the relationship with investors is a collaboration. The partnership theory establishes a division of authority between management (agents) and investors (principals). Jensen \& Meckling (1976) define a contract under one or more involving agents to provide various services for them by delegating decision-making authority to agents. Investors are not permitted to intervene in the technical affairs of the company's activities, resulting in a dispute between management and investors, which causes risks. Conflicts that arise between management acting as agent and shareholders acting as principal can be resolved by the creation of an arbitration agreement by the disputing parties. The basis for conflict settlement rendered in writing by the disputing parties is Law No. 30 of 1999 concerning Arbitration and Alternative Dispute Resolution.

There are two types of Sharia shares recognized in the Indonesian stock market, namely those based on OJK regulation no 35 / POJK.04 / 2017 concerning Criteria and Issuance of Sharia Securities List and those based on OJK regulation no 17 / POJK.04 / 2015 concerning shares listed as Sharia shares by issuers or public approval. The existence of several policies regarding Sharia stocks will consider investors to invest in manufacturing companies that issue Sharia shares, so that we need an analysis of how the return of shares obtained by investors.

Markowitz (1959), from an investor's perspective, predicting the outcome is the essence of accurate financial analysis; thus, financial ratios such as liquidity, activity, and corporate leverage must be considered. Nguyen (2010), the Arbitrage Pricing theory says that stock returns are affected by internal financial variables as determined by financial success. Furthermore, Nastiti et al. (2019) state that investors should weigh two factors: return and risk when investing in stocks. Aveni (2015) discovered that capital market investors would not be isolated from returns and threats, with most investors expecting high returns and minimizing risk. Pratiwi \& Suryanawa (2014), investors must understand potential returns and the risks they face. Some of the risks associated with Sharia stocks include capital loss, liquidity risk, and delisting from the stock exchange, and removal from the Sharia stock list. These are some of the dangers that investors should be aware of. 
Several studies on financial ratios, such as research by Tarmizi et al. (2018), conclude that liquidity, as determined by the current ratio and net profit margin, has no significant impact on stock returns, but Quick ratios and ROE do. Sutriani's (2014) research findings, return on assets and debt to equity ratio affect stock returns and return on assets affect stock returns. As a result, Kusmawati \& Mardani (2018), state that liquidity and activity variable has a significant positive effect on return on equity. Boentoro \& Widyarti (2018), the operation ratio measured by total asset turnover has a substantial positive impact on stock returns, while the leverage ratio measured by debt to equity ratio has a negative but not significant effect. According to research conducted by Oroh et al. (2019), the Return On Asset and Debt To Equity Ratio has no impact on stock returns.

The financial performance produced by the company is an illustration of the company operating to increase profits and increase the company's profitability. For companies that go public always try to improve the welfare of their shareholders, which is reflected in an increase in stock returns. Therefore, the profitability obtained is an indication of the business's success, which will improve the welfare of the shareholders. Setiawan and Triaryati (2016) concluded that profitability has a significant positive effect on stock returns, and profitability can mediate the effect of leverage on stock returns. Windie and Indah (2020) concluded that profitability has a positive effect on Firm Value, Intellectual Capital has an indirect effect on Firm Value, mediated by profitability partially (partial mediation), but does not mediate the effect of Income Diversification on Firm Value. Therefore it is necessary to do further analysis on the mediation of profitability to the measured firm value of the company's stock return.

This research was carried out to assess how management can carry out the company's financial results since good decision-making would enable the company to increase the prosperity of shareholders while increasing the calculated value of stock returns. Furthermore, this research is expected to contribute to management accounting in terms of financial decision-making and appropriate financial policies in both the investment and financing industries, resulting in profitability that may impact dividends or capital gains.

\section{METHOD}

The purposive sampling method was used in this study, in which the sampling was done on purpose following the required sample requirements and specific criteria established by the researchers, such as Manufacturing companies that go public or are classified on the Indonesian Sharia Stock Index (ISSI) and are now trading from 2017 2019, manufacturing companies listed on the Indonesian Sharia Stock Index (ISSI) distribute dividends for 2017-2019, manufacturing companies listed on the Indonesian Sharia Stock Index (ISSI) make an annual report for the years 2017-2019, manufacturing companies listed on the Indonesian Sharia Stock Index (ISSI) make an annual report for the years 2017 - 2019. Eleven companies were chosen as research samples based on these parameters, as shown in Table 1-secondary data collected from the IDX through www. IDX.co.id in the form of data.

The following metrics, three exogenous variables, were used in this study: (1) Liquidity, as determined by the Current Ratio (X1.1), Fast Ratio (X1.2), and Cash Ratio (X1.3) (X1.3). (2) Activities as determined by Inventory Turnover / ITO (X2.1) and Receivable Turnover / RTO (X2.1). (3) Debt-to-Asset Ratio / DAR (X3.1) and Debt-toEquity Ratio / DER (X3.2). (1) Profitability (as measured by Net Profit Margin / NPM

This work is licensed under a Creative Commons Attribution-ShareAlike 4.0 International License. 
(Z1), Return On Asset / ROA (Z2), and Return On Equity / ROE (Z3), and stock returns (as measured by Change in Share Price / PHS (Y1) and Change in Share Volume / PVS) are two endogenous variables (Y2). SEM PLS was used as the analytical instrument.

\section{Table 1. Sample Selection Criteria}

\begin{tabular}{lr}
\hline \multicolumn{1}{c}{ Sample criteria } & Total \\
\hline Manufacturers that went public or registered with ISSI in 2017-2019 & 130 \\
Manufacturing companies that were delisted in the list for the year 2017-2019 & -30 \\
$\begin{array}{l}\text { Manufacturing companies indicated that they did not pay dividends } \\
\text { regularly during the 2017-2019 period }\end{array}$ & -67 \\
$\begin{array}{l}\text { Manufacturing companies that do not publish annual reports regularly or } \\
\text { incomplete for the year during the 2017-2019 period }\end{array}$ & -22 \\
Manufacturing companies that meet the criteria & 11 \\
\hline
\end{tabular}

\section{RESULT AND DISCUSSION}

Rambut et al. (2012) discovered that if an indicator's loading factor value is more significant than 0.5 , it is considered accurate. In principle, confirmatory testing is a popular method for deciding whether an indicator is reliable. This indicates that the indicator can measure the structures it creates. According to the Smart PLS performance, all indicators have a loading factor greater than 0.5, as shown in the Figure 1.

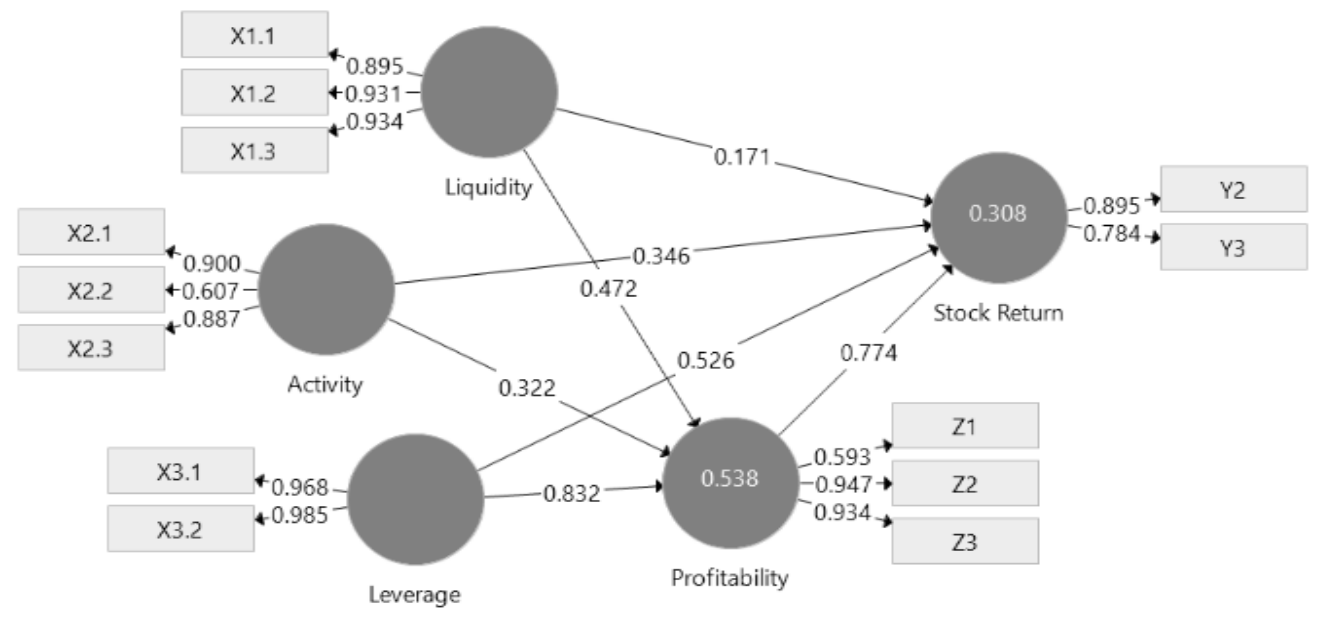

Figure 1. Smart PLS Output for Factor Loading

Based on the results through SEM PLS, with a significant level of $5 \%$, it was found that liquidity had a significant positive effect on profitability $(0.01<0.05)$, activity had a significant positive effect on profitability $(0.04<0.05)$, and leverage had a significant positive effect on profitability $(0.00<0.05)$, liquidity has an insignificant positive effect on stock returns $(0.51>0.05)$, activity has an insignificant positive effect on stock returns $(0.20>0.05)$, and leverage has an insignificant positive effect on stock returns $(0.21>0.05)$, profitability has a significant positive effect on stock returns, $(0.05$ $=0.05)$, as shown in Table 2 .

\section{Liquidity and Profitability}

The impact of liquidity on profitability has been proven to be positive and significant. This study's findings differ from those of Madushanka \& Jathurika (2018), 
who discovered that liquidity has a negative impact on profitability. Liquidity has a negative impact on business profitability, according to Owolabi et al. (2011) and Gunde et al. (2017). According to Novita \& Sofie (2015), liquidity and profitability have a negative relationship. The findings of this study, however, are consistent with those of Meidiyustiani (2016), Putra \& Wiagustini (2019), and Afrinda (2013), who found that liquidity has a significant positive impact on profitability.

Liquidity, which describes the percentage of short-term liabilities that impact the profits, can be obtained; the higher the percentage of short-term liabilities, the lower the profit received because of the high interest payable; and vice versa. As a result, the higher level of liquidity owned by the company, the lower the interest rate, and the higher the level of profitability. Therefore, investors must always pay attention to the liquidity ratio, which helps determine its ability to pay its obligations to third parties. Increasing liquidity through current ratios, quick ratios, cash ratios, and other liquidity-enhancing activities must have strictly adhered to. In this study, there is a significant positive effect of liquidity on profitability in manufacturing companies that issue Sharia shares. It is necessary to pay attention to the provisions of the Sharia, namely profit sharing with investors. The more liquid, the greater the stipulated profitsharing provisions. In addition, it will be a signal to investors that the company can run well, although it will result in risks borne by investors. Partnership cooperation between investors as principals and management as agents will run as expected to minimize the risk that occurs in the event of a conflict between investors and management.

Tabel 2. Variable Testing Results

\begin{tabular}{cccccc}
\hline Variable & $\begin{array}{c}\text { Original } \\
\text { Sample } \\
(\mathrm{O})\end{array}$ & $\begin{array}{c}\text { Sample } \\
\text { Mean } \\
(\mathrm{M})\end{array}$ & $\begin{array}{c}\text { Standard } \\
\text { Deviation } \\
(\text { Stdev })\end{array}$ & $\begin{array}{c}\text { T-Statistics } \\
(\mid \mathrm{O} / \text { Stdev } \mid)\end{array}$ & $\begin{array}{c}\text { P- } \\
\text { Values }\end{array}$ \\
\hline $\begin{array}{c}\text { Liquidity } \rightarrow \\
\text { Profitability }\end{array}$ & 0.472 & 0.425 & 0.191 & 2.472 & $0.014^{*}$ \\
$\begin{array}{c}\text { Liquidity } \rightarrow \text { Stock } \\
\text { return }\end{array}$ & 0.171 & 0.208 & 0.261 & 0.653 & $0.514^{*}$ \\
$\quad \begin{array}{c}\text { Activity } \rightarrow \\
\text { Profitability } \\
\text { Activity } \rightarrow \text { Stock } \\
\text { return }\end{array}$ & 0.322 & 0.373 & 0.162 & 1.968 & $0.047^{*}$ \\
$\quad 0.346$ & 0.352 & 0.273 & 1.268 & $0.205^{*}$ \\
$\begin{array}{c}\text { Leverage } \rightarrow \\
\text { Profitability }\end{array}$ & 0.832 & 0.704 & 0.313 & 2.659 & $0.008^{*}$ \\
$\begin{array}{c}\text { Leverage } \rightarrow \text { Stock } \\
\text { return }\end{array}$ & 0.526 & 0.526 & 0.421 & 1.250 & $0.212^{*}$ \\
$\begin{array}{c}\text { Profitability } \rightarrow \text { Stock } \\
\text { return }\end{array}$ & 0.774 & 0.775 & 0.284 & 2.728 & $0.007^{*}$ \\
\hline
\end{tabular}

Notes: * Significant level $<0,05$

\section{Liquidity and Stock Returns}

The test results to see how liquidity affects stock returns show that it has a negligible impact. The findings of this study contradict those of Sari \& Wahyudi (2012), who discovered that liquidity has a positive and significant impact on stock returns. Liquidity is an essential factor in determining the return price, according to Marozva (2019), because excess returns on shares are positively related to liquidity, and the 
relationship is substantial. Furthermore, Fitriana et al. (2016), Dewi (2017), and Tarmizi et al. (2018) discovered a positive but minor relationship between liquidity and stock returns.

The condition when the research was conducted, where a decline in economic growth resulted in a decrease in company liquidity. Liquidity is measured by $C R, Q R$, and Cash Ratio, which should describe the higher these ratios, the better the company's profits and returns to investors. However, this study states that there is an insignificant influence between liquidity and stock returns, which means that the more liquid it will have no impact on stock returns to investors. This needs the attention of management as an agent and will be a signal for investors because there is a concern that they will not get a return on their investment in the form of dividends or capital gains.

The analysis can be concluded that in the conditions of the study period, where the company's ability to increase the liquidity ratio is used to improve the company's operational management so that the income earned is mostly used to support the company's operational development. It should be noted that there is a concern that there will be conflicts between management and investors because, based on the theory of Jensen and Meckling (1976), investors are not allowed to interfere in the technical affairs of the company's operations, which creates a conflict between management and investors, which raises risks. If it is not paid attention to, it will have an impact on the sustainability of the company.

\section{Activity and Profitability}

The activity analysis's findings have a substantial positive impact on profitability. This contradicts the findings of Taani (2011), Putri (2018), and Jumhana (2017), who found that activity boosts profits. According to Ambarwati et al. (2015), Putri \& Musmini (2013), Nuriyani \& Zannati (2017), activity has a positive and significant impact on profitability.

A good governance system that includes all elements of the company, both current and fixed assets, is required when managing company assets. The company's current assets are related to its day-to-day operations, with the ultimate goal of increasing sales. Fixed assets are assets used and supported in the execution of company operations and assets that bear fixed expenses that the company bears regularly. Asset management combined with good governance will improve a company's operational performance and profitability. On the other hand, poor corporate governance can hurt a company's profitability.

The company's activities describe how it manages its assets in the hopes of achieving a high rate of return through good management. The higher the ITO and RTO, the faster the return on the company's assets. A high ITO turnover rate in inventory turnover speed to cash will speed up the return of funds from inventory and the return of accounts receivable. As a result, the company's NPM, ROA, and ROE will improve. This indicates that the company's refund will be used to fund operations soon to maximize revenue. As a result, profits will be acquired faster, and the company's profitability will be increased.

The effect of the two variables shows that with a healthy activity ratio, for example, the ratio of accounts receivable that has a high turnover rate, the profitability will also be healthy because it avoids the cost of bad debts. In this study, there is a significant positive effect of activity on profitability in manufacturing companies that issue Sharia shares; it is necessary to pay attention to the Sharia provisions, namely profit sharing with investors. The higher the activity ratio, the higher the profitability and the greater the profit-sharing provisions set. In this condition, although the 
Signaling theory states that the principle of the partnership that occurs creates a separation of authority between management (agents) and investors (principals), investors will feel calm because an increase in company activity will increase profitability, thereby minimizing the risk borne by investors.

\section{Activity and Stock Returns}

The results revealed that the activity ratio had no significant impact on stock returns. Dewi (2017), on the other hand, discovered that operations have a positive and significant impact on stock returns. Activity has a significant effect on the prediction of stock returns, according to Alan et al. (2014) and Darmawan \& Astuti (2016). The Activity Ratio has a positive but marginal effect on stock returns, according to Pratama \& Idawati (2019), Antara et al. (2014), and Lestari et al. (2016).

Activities and other non-investing and non-financing activities provide most of the Company's revenue. These are derived from sales and other activities that impact net profit or loss and are used to determine whether a company can generate enough cash from its operations to pay off debt, maintain operating capacity, pay dividends, and make new investments without relying on outside financing. The greater the size of a company's operations, the higher the investor confidence in it, and thus the higher the stock return value. The lower a company's operations are the lower investor confidence, thus lowering the stock return value.

Company management and investors understand that these actions do not guarantee the company's ability to continue operating in the future, they are assumed to have little impact on stock returns in this report. Dividends can be paid to shareholders by companies with high profits and sufficient cash reserves.

As previously stated, activities describe how a company manages its assets measured in this study by ITO and RTO. The higher the ratio, the faster the company's assets are repaid. This occurs when asset management is done correctly, resulting in a high rate of return for the company. Good asset management governance will directly increase company profits and profitability.

Investors will invest if they get a good return, so going public companies that want to increase shareholders need to pay attention. The company's revenue will be used to improve performance, but several other factors must be improved, such as company operations and development for long-term sustainability and adding company assets. As a result, an increase in company activity does not necessarily imply an increase in investors' expected return on the stock. The insignificant effect between activities on stock returns on Sharia shares that use the principle of partnership raises concerns from investors that based on the signaling shop; there is a transfer of authority between management and agents. Investors' concerns occur because the increase in company activity does not optimally support the return of healthy shares, which should be accepted by investors. This is a concern for investors in the sustainability of investors in investing.

\section{Leverage and Profitability}

Leverage has been shown to have a positive and significant impact on profitability. This study's findings contradict those of Alarussi \& Alhaderi (2018), who claim that leverage has no impact on profitability. Leverage has no significant effect on profitability, according to Rangkuti et al. (2017), Coricelli et al. (2012), and Ali (2014). However, according to Salehi \& Manesh (2012), capital structure (leverage) has a significant positive impact on profitability. According to Chen \& Chen's (2011) 
research, leverage has a significant positive impact on profitability. Kodongo et al. (2015) came to the same conclusion, stating that leverage has a significant positive impact on company profitability.

The leverage ratio is a calculation that compares a company's total debt to its assets or equity. DAR and DER are used to calculate the leverage ratio in this study. This ratio indicates how much of the company's assets are owned by shareholders versus creditors' assets. Companies that go public, where the owners are shareholders, show that the higher the proportion of debt provided by shareholders, the lower the risk faced by creditors because creditors view equity or funds provided by owners as a safety limit. Furthermore, if the results obtained from the company's assets are higher than the interest rate paid, then the use of debt will increase ROE.

It can be concluded from this explanation that increasing debt will increase the company's profitability. This demonstrates that leverage is one of the most critical factors influencing profitability. In addition, an increase in profitability due to an increase in corporate debt indicates that the company can manage its assets and capital, resulting in inefficient use of the company's assets and capital. The existence of this efficiency will have an impact on increasing the company's profitability. In this condition, investors will have more confidence in the company so that investors' expectations of earning income will be achieved and the risks they bear will be lower.

\section{Leverage and Stock Return}

According to the leverage test results, the impact of leverage on stock returns is insignificant, according to the results of the leverage test. This contradicts Sari \& Wahyudi's (2012) findings, which found that leverage has a significant positive effect on stock returns. According to Mariani et al. (2016) and Sutriani (2014), leverage has a positive and significant impact on stock returns. This finding supports the findings of Putra \& Dana (2016), Arista \& Astohar (2012), and Hatta \& Dwiyanto (2012), who discovered that leverage has a significant and positive effect on stock returns.

According to Brigham \& Houston (2015), when a company goes public, and the owners are shareholders, the higher the proportion of debt provided by shareholders, the lower the creditors' risk because creditors look at the equity or funds provided. The use of debt will increase ROE if the results obtained from the company's assets are higher than the interest rate paid by the owner as a safety limit. Because the shareholders refer to the safety limit, more significant debt will send negative signals from share winners. As a result, investors will be concerned if the leverage ratio, as measured by DAR and DER, rises. The findings of this study show that the position of debt based on assets changes over time, while the position of debt based on equity has little impact on stock returns. This means that the leverage ratio will have no impact on investors' investment decisions. Even if the findings are irrelevant, investors should not disregard the company's debt ratio. For businesses, failure to pay debts is a common source of financial distress. The higher the debt-to-income ratio, the higher the fixed payments, and the greater the risk of bankruptcy.

The company's goal is to improve the welfare of shareholders, so it needs attention, considering that investors will invest if they get a good return. The company's revenue will be used to improve the company's performance, which can come from the efficient use of debt. But there are many factors that must be improved, including company operations and development for company sustainability, adding company assets, and so on so that an increase in the use of corporate debt will not guarantee an increase in the rate of return on shares expected by investors. The insignificant effect between leverage on stock returns on Sharia stocks using the

http://doi.org/10.25273/jap.v10i1.8749 
partnership principle. If what is based on the signaling shop states that there is a separation of authority between management as an agent and investors as principals who have different interests, besides that investors are not allowed to interfere in the internal company, which raises concerns from investors. Investors' concerns occur because the increase in the company's leverage does not optimally support the return of shares that should be received by investors. This is a concern and an initial signal for investors in investing in sustainability.

\section{Profitability Mediation In Liquidity, Leverage, And Activity On Stock Returns}

According to the findings, profitability positively and significantly affects mediating liquidity on stock returns. This indicates that the company's debt has decreased, resulting in a reduction in the company's amount of interest. This will undoubtedly increase the company's profits. Profitability is unquestionably a good indicator for investors looking to put their money into a company. The higher the demand for a company's shares, the higher the share price and profit. According to the findings, profitability acts as a complete mediator in the impact of liquidity on stock returns. Profitability's role is to act as a middleman for investors buying and selling manufacturing company shares. This finding is consistent with Wibowo \& Wartini's (2012) findings, which found that the liquidity ratio, which is proxied by profitability, can influence stock returns.

According to these findings, profitability positively and significantly impacts stock returns mediation activity. An increase in activity valuation translates to an increase in business income, which translates to a significant profit. Large profits are a good sign for investors because they show that assets are being used to generate profits effectively. The amount of profit often illustrates the company's good results, which causes the market to respond positively, as evidenced by the company's increased profits. The increase in operating value indicates that the company's revenue generation success is improving. This ensures that investors will receive a higher rate of return on their shares if the company can meet its short-term obligations. This study's findings are consistent with those of Setiawan \& Triaryati (2016) and Al-Fisah (2016), who found that substantial profitability mitigates the impact of leverage on stock returns.

According to the findings, profitability has a positive and significant influence in mediating leverage on stock returns. Low leverage refers to a small business's total debt, which lowers the amount of interest it must pay. As a result, the organization's profits increase. This is appealing to investors because the risks are low compared to the potential rewards. According to Setiawan \& Triaryati (2016) and Al-Fisah (2016), profitability significantly and positively mediates the effect of leverage on stock returns. These activities will affect profit margins and, as a result, will be able to provide a signal in the capital market, causing the issuer's stock returns to rise. This study's findings are in line with those of Yuliani et al. (2016), who discovered that activity has a significant impact on stock returns. These findings suggest that increasing investment levels will result in higher business income and increased stock returns.

Manufacturing firms with high liquidity, low debt, and favorable company activity ratios will frequently consider profitability before reporting stock returns. The profitability factor must be considered until it is disclosed because if a business does not have high profits, it will prioritize demands for high profits, increased profitability, and increased profitability. As a result, the company's profitability improves the 
relationship between liquidity, activity, and leverage when disclosing stock returns. In contrast to Agustin et al. (2019), Alavinasab \& Davoudi (2013), and Nadyayani \& Suarjaya (2021), who found no significant effect on stock returns, profitability has a significant effect on stock returns. It also aligns with Handriani \& Robiyanto's (2018) findings, who discovered that profitability significantly impacts stock returns. Profitability fully mediates the effect of liquidity, operations, and leverage on stock returns, according to Yuliani et al. (2016).

According to the above explanation, profitability is a variable that fully mediates the effect of liquidity, activity, and leverage on stock returns in manufacturing companies listed on the IDX and the Indonesian Sharia Stock Index (ISSI) between 2017 and 2019. The study's findings show that manufacturing firms that issue Islamic stocks must pay attention to profits because they impact the rate of return on shares for investors. However, it should be noted that there is a distinction between traditional stocks and Islamic stocks, which are a choice or alternative for investors to consider while investing. The benefit on Sharia shares must be calculated in compliance with the Maqosid Syariah laws. As a result, socialization and education are needed to increase investor interest in Sharia stocks.

\section{CONCLUSION}

This research aimed to find an empirical explanation for the role of profitability as a moderator in the effect of liquidity, activity, and leverage on stock returns. Profitability is expected to impact stock returns, with higher profitability leading to higher stock returns. Shareholders will receive more money as income rises and vice versa. Many factors must be optimized to increase revenue, including liquidity, activity, and leverage.

The impact of variables such as liquidity, activity, and leverage on significant positive profitability. This shows that liquidity, activity, and leverage all positively and significantly impact profitability, implying that increasing exogenous variables will increase company income and investor interest in its stock. Meanwhile, even though market output is optimal, the variables of liquidity, activity, and leverage have a positive effect. However, they have a minor impact on the stock return variable, indicating that the stock return variable is not directly affected by liquidity, activity, or leverage.

In practice, these findings remind investors that when deciding whether or not to invest in stocks, they should consider the profitability of companies and potential investors. Liquidity, operations, and leverage, on the other hand, should be ignored by investors because they have no bearing on stock returns. Investors can use the company's high levels of liquidity and activity and low leverage levels to analyze the financial statements before purchasing shares in the target business. The calculated benefit in Sharia shares must comply with the Maqosid Syariah laws. As a result, socialization and education are needed to increase investor interest in Sharia stocks.

\section{REFERENCES}

Afrinda, N. (2013). Analisis Pengaruh Likuiditas dan Solvabilitas terhadap profitabilitas pada perusahaan makanan dan minuman yang terdaftar di Bursa Efek Indonesia (BEI). Palembang. Fakultas Ekonomi Universitas Sriwijaya.

Agustin, M., AR, M. D., \& Darmawan, A. (2019). Analysis Of The Effect Of Firm Size, Financial Leverage, Profitability, Diversification On Market Risk and Stock Return (Case Study of Manufacturing Companies in the Consumer Goods Industry Sector Listed on the Indonesia Stock Exchange in 2007-2016). The 
International Journal of Accounting and Business Society, 27(3), 28-55.

Al-Fisah, M. C. (2016). Profitabilitas Memediasi Pengaruh Struktur Modal Terhadap Nilai Perusahaan Properti Yang Terdaftar Di Bursa Efek Indonesia (BEI). STIESIA SURABAYA.

Alan, Y., Gao, G. P., \& Gaur, V. (2014). Does inventory productivity predict future stock returns? A retailing industry perspective. Management Science, 60(10), 2416-2434. https://doi.org/10.1287/mnsc.2014.1897

Alavinasab, S. M., \& Davoudi, E. (2013). Studying the relationship between working capital management and profitability of listed companies in Tehran stock exchange. Business Management Dynamics, 2(7), 1-8.

Ali, M. (2014). Relationship between Financial Leverage and Financial Performance (Evidence of Listed Chemical Companies of Pakistan). Research Journal of Finance and Accounting, 5(23), 46-56.

Ambarwati, N. S., Yuniarta, G. A., AK, S. E., \& Sinarwati, N. I. K. (2015). Pengaruh modal kerja, likuiditas, aktivitas dan ukuran perusahaan terhadap profitabilitas pada perusahaan manufaktur yang terdaftar di bursa efek Indonesia. JIMAT (Jurnal Ilmiah Mahasiswa Akuntansi) Undiksha, 3(1).

Antara, S., Sepang, J., \& Saerang, I. S. (2014). Analisis rasio likuiditas, aktivitas, dan profitabilitas terhadap return saham perusahaan wholesale yang terdaftar di bursa efek Indonesia. Jurnal EMBA: Jurnal Riset Ekonomi, Manajemen, Bisnis Dan Akuntansi, 2(3).

Arista, D., \& Astohar, A. (2012). Analisis Faktor-Faktor Yang Mempengaruhi Return Saham. Jurnal Ilmu Manajemen Dan Akuntansi Terapan (JIMAT), 3(1).

Aveni, T. (2015). New Insights Into An Evolving P2P Lending Industry: how shifts in roles and risk are shaping the industry. Positive Planet Group, August.

Beik, I. S., \& Fatmawati, S. W. (2014). Pengaruh Indeks Harga Saham Syariah Internasional dan Variabel Makro Ekonomi Terhadap Jakarta Islamic Index. AlIqtishad: Jurnal Ilmu Ekonomi Syariah, 6(2), 155-178. https://doi.org/10.15408/aiq.v6i2.1228

Boentoro, N. V., \& Widyarti, E. T. (2018). Analisis Pengaruh Rasio Likuiditas, Leverage, Profitabilitas, Aktivitas Dan Pasar Terhadap Return Saham (Studi Kasus: Perusahaan Consumer Goods yang terdaftar di Bursa Efek Indonesia periode 2012 sampai dengan 2016). Fakultas Ekonomika dan Bisnis.

Brigham, E. F., \& Houston, J. F. (2015). Fundamentals of Financial Management. Cengage Learning. https://books.google.co.id/books?id=7T9-BAAAQBAJ

Chen, L.-J., \& Chen, S.-Y. (2011). The influence of profitability on firm value with capital structure as the mediator and firm size and industry as moderators. Investment Management and Financial Innovations, 8, Iss. 3, 121-129.

Coricelli, F., Driffield, N., Pal, S., \& Roland, I. (2012). When does leverage hurt productivity growth? A firm-level analysis. Journal of International Money and Finance, 31(6), 1674-1694. https:/ / doi.org/10.1016/j.jimonfin.2012.03.006

Darmawan, R., \& Astuti, D. S. (2016). Pengaruh Return on Asset Dan Inventory Turnover Terhadap Harga Saham. Jurnal, 3(3), 109-114.

Dewi, P. E. D. M. (2017). Pengaruh Rasio Likuiditas, Profitabilitas, Solvabilitas, Aktivitas Dan Penilaian Pasar Terhadap Return Saham. Jurnal Ilmiah Akuntansi, 1(2), 109-132. https:// doi.org/10.23887/jia.v1i2.9988

Fitriana, D., Andini, R., \& Oemar, A. (2016). Pengaruh likuiditas, solvabilitas, profitabilitas, aktivitas dan kebijakan dividen terhadap return saham perusahaan pertambangan yang terdaftar pada BEI periode 2007-2013. Journal of Accounting,

This work is licensed under a Creative Commons Attribution-ShareAlike 4.0 International License. 
2(2).

Gunde, Y. M., Murni, S., \& Rogi, M. H. (2017). Analisis Pengaruh Leverage Terhadap Profitabilitas Pada Perusahaan Manufaktur Sub Industri Food and Beverages Yang Terdaftar Di Bei (Periode 2012-2015). Jurnal EMBA: Jurnal Riset Ekonomi, Manajemen, Bisnis Dan Akuntansi, 5(3). https://doi.org/10.35794/emba.v5i3.18382

Hair, J. F., Sarstedt, M., Pieper, T. M., \& Ringle, C. M. (2012). The Use of Partial Least Squares Structural Equation Modeling in Strategic Management Research: A Review of Past Practices and Recommendations for Future Applications. Long Range Planning, 45(5-6), 320-340. https:/ / doi.org/10.1016/j.lrp.2012.09.008

Hatta, A. J., \& Dwiyanto, B. S. (2012). The company fundamental factors and systematic risk in increasing stock price. Journal of Economics, Business, \& Accountancy Ventura, 15(2), 245-256.

Jensen, M. C., \& Meckling, W. H. (1976). Theory of the firm: Managerial behavior, agency costs and ownership structure. Journal of Financial Economics, 3(4), 305360.

Jumhana, R. C. S. (2017). Pengaruh Rasio Likuiditas Dan Rasio Aktivitas Terhadap Profitabilitas Pada Koperasi Karyawan PT Surya Toto Indonesia Jurnal Sekuritas Prodi Manajemen Unpam. Jurnal Sekuritas, 11(22), 54-73.

Kodongo, O., Mokoaleli-Mokoteli, T., \& Maina, L. N. (2015). Capital structure, profitability and firm value: panel evidence of listed firms in Kenya. African Finance Journal, 17(1), 1-20.

Kusmawati, S., \& Mardani, R. M. (2018). Pengaruh Rasio Profitabilitas, Likuiditas, Aktivitas Terhadap Return Saham Pada Perusahaan Farmasi Yang Terdaftar Di Bursa Efek Indonesia Pada Tahun 2013-2016. Jurnal Ilmiah Riset Manajemen, $7(8)$.

Lestari, K., Andini, R., \& Oemar, A. (2016). Analisis Likuiditas, Leverage, Profitabilitas, Aktivitas, Ukuran Perusahaan dan Penilaian Pasar Terhadap Return Saham (Pada Perusahaan Real Estate dan Property di BEI) Periode Tahun 2009-2014. Journal Of Accounting, 2(2).

Madushanka, K. H. I., \& Jathurika, M. (2018). The impact of liquidity ratios on profitability. International Research Journal of Advanced Engineering and Science, 3(4), 157-161. https://www.irjaes.com/pdf/V3N4Y18-IRJAES/IRJAESV3N4P297Y18.pdf

Mariani, N. L. L., Yudiaatmaja, F., Yulianthini, N. N., \& SE, M. M. (2016). Pengaruh profitabilitas dan leverage terhadap return saham. Jurnal Manajemen Indonesia, $4(1)$.

Markowitz, H. (1959). Portfolio selection. Yale University Press New Haven.

Marozva, G. (2019). Liquidity and Stock Returns: New Evidence From Johannesburg Stock Exchange. The Journal of Developing Areas, 53(2), 79-90. https://doi.org/10.1353/jda.2019.0022

Meidiyustiani, R. (2016). Pengaruh Modal Kerja, Ukuran Perusahaan, Pertumbuhan Penjualan dan Likuiditas terhadap Profitabilitas pada perusahaan manufaktur sektor industri barang konsumsi yang terdaftar di Bursa Efek Indonesia (BEI) periode tahun 2010-2014. Jurnal Akuntansi Dan Keuangan, 5(2), 41-59.

Nadyayani, D. A. D., \& Suarjaya, A. A. G. (2021). The Effect of Profitability on Stock Return. American Journal of Humanities and Social Sciences Research (AJHSSR), 5(1), 695-703.

Nastiti, P. K. Y., Atahau, A. D. R., \& Supramono, S. (2019). Working capital management and its influence on profitability and sustainable growth. Business: 
Theory and Practice, 20, 61-68. https://doi.org/10.3846/BTP.2019.06

Nguyen, T. D. (2010). Arbitrage Pricing Theory: Evidence from an emerging stock market. Development and Policies Research Center Working Paper Series, 2010/03.

Nuriyani, N., \& Zannati, R. (2017). Pengaruh Perputaran Kas dan Perputaran Piutang Terhadap Profitabilitas Perusahaan Sub-Sektor Food and Beverages Tahun 20122016. Jurnal Riset Manajemen Dan Bisnis (JRMB) Fakultas Ekonomi UNIAT, 2(3), 425-432.

Oroh, M. M., Van Rate, P., \& Kojo, C. (2019). Pengaruh Profitabilitas Dan Leverage Terhadap Return Saham Pada Sektor Pertanian Di Bei Periode 2013-2017. Jurnal EMBA: Jurnal Riset Ekonomi, Manajemen, Bisnis Dan Akuntansi, 7(1).

Owolabi; Obiakor; Okwu. (2011). Investigating Liquidity-Profitability Relationship in Business Organizations: A Study of Selected Quoted Companies in Nigeria. 1 (September).

Pratama, I. G. S., \& Idawati, I. A. A. (2019). Pengaruh Rasio Keuangan Terhadap Return Saham Pada Perusahaan Pertanian Di Bursa Efek Indonesia. WICAKSANA: Jurnal Lingkungan Dan Pembangunan, 3(1), 38-44.

Pratiwi, N., \& I.Kt.Suryanawa. (2014). Pengaruh Good Corporate Governance Dan Corporate Social Responsibility Disclosure Pada Return Saham. E-Jurnal Akuntansi Universitas Udayana, 9(2), 465-475. https://ocs.unud.ac.id/index.php/Akuntansi/article/view/9245

Putra, I. M. G. D., \& Dana, I. M. (2016). Pengaruh profitabilitas, leverage, likuiditas dan ukuran perusahaan terhadap return saham perusahaan farmasi di BEI. E-Jurnal Manajemen, 5(11).

Putra, Y. Y. D., \& Wiagustini, N. L. P. (2019). Pengaruh Likuiditas Dan Leverage Terhadap Profitabilitas Dan Nilai Perusahaan Pada Perusahaan Perbankan Di BEI. JWM (Jurnal Wawasan Manajemen), 1(2), 215-232.

Putri, L. P. (2018). Pengaruh Aktivitas Terhadap Profitabilitas Perusahaan Konstruksi Dan Bangunan Di Indonesia. Jurnal Seminar Nasional Royal (SENAR), 9986(September), 465-468.

Putri, L. R., \& Musmini, L. S. (2013). Pengaruh Perputaran Kas Terhadap Profitabilitas Pada Pt. Tirta Mumbul Jaya Abadi Singaraja Periode 2008-20012. Jurnal Akuntansi Profesi, 3(2).

Rangkuti, Z. R., Pratomo, D., \& Kurnia. (2017). Pengaruh Karakter Eksekutif dan Leverage terhadap Tax Avoidance (Studi Kasus pada Perusahaan Manufaktur Subsektor Pertambangan Batubara yang Terdaftar di Bursa Efek Indonesia tahun 2011-2015). E-Proceeding of Management, 4(1), 533-541.

Salehi, M., \& Manesh, N. B. (2012). A study of the roles of firm and country on specific determinates in capital structure: Iranian evidence. International Management Review, 8(2), 51-62.

Sari, N. F., \& Wahyudi, S. (2012). Analisis Pengaruh DER, CR, ROE, dan TAT terhadap Return Saham (Studi pada Saham Indeks LQ45 periode 2009-2011 dan Investor yang Terdaftar pada Perusahaan Sekuritas di Wilayah Semarang periode 2012). Fakultas Ekonomika dan Bisnis.

Setiawan, P. B. R., \& Triaryati, N. (2016). Peran Profitabilitas dalam Memediasi Pengaruh Leverage Terhadapreturn Saham pada Perusahaan Food And Beverages. E-Jurnal Manajemen, 5(5).

Sutriani, A. (2014). Pengaruh Profitabilitas, Leverage, Dan Likuiditas Terhadap Return Saham Dengan Nilai Tukar Sebagai Variabel Moderasi Pada Saham Lq-45.

This work is licensed under a Creative Commons Attribution-ShareAlike 4.0 International License. 
Journal of Business and Banking, 4(1), 67. https:// doi.org/10.14414/jbb.v4i1.294

Taani, K. (2011). The effect of financial ratios, firm size and cash flows from operating activities on earnings per share:(an applied study: on Jordanian industrial sector). International Journal of Social Sciences and Humanity Studies, 3(1), 197-205.

Tarmizi, R., Soedarsa, H. G., Indrayenti, I., \& Andrianto, D. (2018). Pengaruh Likuiditas dan Profitabilitas Terhadap Return Saham. Jurnal Akuntansi Dan Keuangan, 9(1), 13.

Wibowo, A., \& Wartini, S. (2012). Efisiensi Modal Kerja, Likuiditas dan Leverage terhadap Profitabilitas pada Perusahaan Manufaktur di BEI. JDM (Jurnal Dinamika Manajemen), 3(1).

Wijayanti, E., \& Yuliana, I. (2020). Risk Profile, Secure Bond, and Bond Rating in Banking Industry. The Winners, 21(1), 49-57.

Yuliani, Y., Kurniawan, T., \& Ghasarma, R. (2016). Pengaruh likuiditas, financial leverage, aktivitas terhadap return saham dengan profitabilitas sebagai variabel mediasi. Jurnal Manajemen Dan Bisnis Sriwijaya, 14(1), 121-132.

Yustyarani, W., \& Yuliana, I. (2020). Efek Mediasi Profitabilitas: Modal Intelektual, Diversifikasi Pendapatan dan Nilai Perusahaan. Esensi: Jurnal Bisnis dan Manajemen, 10(1), 83-94. 